\title{
Employee Ownership And Corporate Governance: Evidence From The French Market
}

\author{
Tarek Ben Noamene, University of Law, Economics, and Management of Jendouba, Tunisia
}

\begin{abstract}
This paper's objective is to study the issue of employee ownership in the context of corporate governance. We show first that the literature is controversial on the role that employeesshareholders may play in the corporate governance system and consequently in value creation. In a second step, we empirically analyse the performance of a sample of companies from the index SBF 250. Our results show a negative relationship between the presence of employee shareholders in the control bodies (board of director or board of trustees) and financial performance indicators.
\end{abstract}

Keywords: Employee Ownership; Corporate Governance; Managerial Entrenchment; Corporate Performance

\section{INTRODUCTION}

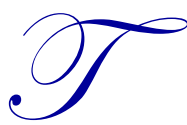

he study of employee ownership in a French context is motivated by the important development that this practice scores at both the firm and the political levels. According to the French Federation of Employees-Shareholders (FAS, 2012), 91\% of listed firms set employees-shareholders ownership plans. Average rate of capital held by employees is $4 \%$ and nearly 4 million employees are affected by these plans. Value of employees-shareholders share is around 36 billion Euros, or 38\% of employees' savings.

This enthusiasm for employees-shareholders ownership in France is justified by political interest. Indeed, the legislative reforms on employees-shareholders ownership have been advanced like the 1986 Law on Privatization, the Fabus Act 2001, the Fillon Act of 2003, the Law on Participation and Employees-Shareholders Ownership of December 30, 2006, and finally, the 2008 Act in Favour of Labour Income.

This political will to promote employees-shareholders ownership in French companies is clearly seen, especially with the advent of the 30 December 2006 law. Pursuant to Article 32 of Law No. 2006-1770 of 30 December 2006, the boards of directors or supervisory boards of listed companies are required to hold at least an administrator, not a trade unionist, to represent employees-shareholders.

Following the enactment of the Act, $26 \%$ of listed companies have become committed. For others, the representation of employees is optional. Therefore, it is legitimate to wonder about the effects of this law on the functioning of corporate governance system. Such consequences will be measured through the impact of this representation on the financial performance of the studied companies.

Our study is therefore interested in studying the effects of the representation of employees-shareholders in corporate governance before and after the entry into force of legal provisions.

The previous literature has not explored the issue of mandatory representation of employees-shareholders. Most of the studies have treated the effects of employees-shareholders ownership on firm performance. The study of Hollandts et al. (2011), which focused on examining the determinants of performance of employees-shareholders outside legal requirements, suggests the possibility of using employees-shareholders share plans for purposes of managerial entrenchment. 
The Anglo-Saxon context and the controversial conclusions tend to confirm the hypothesis of a managerial opportunism because employees-shareholders are deemed loyal and passive towards their managers (Hollandts et al., 2008).

We aim at determining the extent mandatory representation of employees-shareholders in supervisory bodies, as provided by the 2006 Act, affects functioning of corporate governance and hence its performance. First, we make recourse to different theoretical and empirical studies that have addressed the relationship between employees-shareholders ownership and performance in the context of corporate governance. Then, we try to bring in an empirical explanation to our research questions through the study of a sample of firms listed on the SBF 250 index.

\section{LITERATURE REVIEW}

Some authors assume that the double investment made by employee-shareholders establishes the usefulness of their presence in the corporate governance system. By participating in ratification and monitoring (Fama \& Jensen, 1983), they are forcibly urged to effectively exercise their control over executives.

The use, therefore, of the "risk" argument, which legitimizes external shareholders as natural control holders, similarly amounts to legitimize employee shareholders to participate in corporate governance as they deploy both their human and financial capital. They even increase more their overall risk (Desbrières, 1997).

When employees become part owners of the firm capital, they become more involved in its management and performance (Desbrières, 2002). By becoming shareholders, they incur on the one hand, a residual risk proportional to their contribution in the firm's human capital as employees and on the other hand a risk related to the funds they have invested as shareholders (Desbrières, 1997). They are therefore particularly encouraged to protect their investment by controlling managers' opportunistic behaviour, because they may suffer directly the consequences (Hollandts et al., 2008).

The presence of employee shareholders in firm control gives them an additional informational advantage. They can exploit information available to them as employees, and those obtained in shareholders meetings. This particular position should then allow them to effectively control managers, and align decisions with their interests (Gharbi \& Lepers, 2008).

Gamble (2000) stresses that employee-shareholders have a privileged position in the firm, as such they enjoy physical proximity with top management. Desbrières (2002) suggested that the presence of employee shareholders in firm control is highly favorable to external shareholders. Their presence in the board of directors or board of trustees reduces the propensity that executives have of self-designation as a primary source of performance for the company.

For Poulain-Rehm (2006), participating in ratification and monitoring (Fama \& Jensen, 1983), employeeshareholders are well positioned to ensure compliance with their interests and to safeguard their dual investment. Ultimately, employee-shareholders can play a significant role in corporate governance system through a combination of the two positions that allow them to have informational advantages and physical proximity with top management (Zolezzi, 2004).

However, their role as independent directors seems limited. Several authors support the hypothesis that employee-shareholders cannot detach themselves from their dependence on executives and thus may not counter their decisions (Gharbi, 2006).

Moreover, employee-shareholders' ability to ensure their "controller" roles seem to depend on their access to information and their influence in the control body, which is weighted by the percentage of shares they hold (Desbrières, 2002). 
"The power of employee-shareholders is measured by the ability to influence decisions of the board (...) Their motivation to effectively control executives is an increasing function of firm-specific investment in both human capital and equities" Desbrières (2002, p. 264).

Several authors consider employee ownership as a practice that would strengthen managers' opportunism and rooting (Chaplinsky \& Niehaus, 1994; Gamble, 2000; Gordon \& Pound, 1990; Gharbi, 2006; Gharbi \& Lepers, 2008; Hollandts et al., 2011; Pugh et al., 1999).

Indeed, the hierarchical relationships and dependence which bind employee-shareholders to executives, effectively prevent them from exercising their duties as independent directors (Gharbi, 2006). On the other hand, managers can implement several mechanisms to increase employees' dependence to them, such as implicit contracts or possible cooperation strategies (Gamble, 2000). Implicit contracts arranged by executives with employeeshareholders can lead to promises of wage increases, evolution, and training or also to threats of layoffs. According to Parrat (1999), promises of promotion or salary increase aim at gaining employees' support in case of conflict of interest with shareholders.

The literature has raised two types of relationships that seem to reflect the main objective of the executives encouraging the establishment of employee ownership plans:

The first, called an "indirect," suggests that executives set up employee ownership plans with the objective of tax benefits (Autenne, 2005). Executives tend to favour this type of remuneration compared to other forms such as salary increases (Vaughan-Whitehead, 1992).

The second, considered "direct," suggests that by introducing employee ownership, executives seek to protect themselves against possible hostile takeovers and preserve the autonomy of the enterprise and internal cohesion (Chang, 1990; Chaplinsky \& Niehaus, 1994; Park \& Song, 1995; Rauh, 2004).

Moreover, employee-shareholders tend to oppose takeovers of which they may be victims if they involve layoffs. By maintaining the existing management team, they ensure that their implicit contracts will be executed well. This produces a risk of collusion and mutual protection between managers and employee-shareholders (Desbrières, 2002).

As highlighted by Trébucq (2002, p. 112) "... employees' dependence position, eager to safeguard their jobs and human capital, can lead them to demand that their representative almost unwaveringly supports their managers. Thus employee-shareholders, fearing a possible dismissal, are exploited without their knowledge to thwart possible hostile takeovers. In these circumstances, corporate governance mechanisms ensure external discipline of managers, although the financial and labour markets are no longer operative."

Thus, the presence of representatives of employee shareholders greatly reduces effectiveness of monitoring and evaluation strengthening corporate governance (Trébucq, 2002).

Several empirical studies confirm managers' use of employee ownership for purposes of rootin. Thus, Chang (1990) showed that introducing ESOP (Employee Stock Ownership Plan) was seen as a defensive strategy of managerial rooting. The results confirm the unfavourable market reaction when ESOP follows a takeover attempted.

Gordon and Pound (1990) find that announcing the establishment of an ESOP would be the signal of a future takeover attempt. The results of their study, and those of Chang and Mayers (1992) and Conte et al. (1996), support the hypothesis of managerial rooting.

Chaplinsky and Niehaus (1994), Dhillon and Ramirez (1994) and Park and Song (1995) clearly confirmed the use of employee ownership plans for defensive purposes and rooting.

Pugh, Oswald, and Jahera (1999) observed a simultaneous use of employee ownership and debt in companies likely to be subject to a public takeover bid. Gamble (2000) notes a reduced risk of external takeovers for companies with ESOP. 
Generally, employee ownership, as a defensive mechanism, strengthens the position of executives by limiting the risk of hostile takeovers (Pendleton et al., 1998; Pendleton, 2001).

The recent study of Hollandts et al., (2011), sought to determine the history of representation of employee shareholders on the board of directors, confirms the management rooting hypothesis.

Overall, conclusions on the role of employee-shareholders in corporate governance are controversial. On the one hand, employee ownership is a tool of corporate governance, insofar as its incentive component may induce employees to ensure effective control on managers to protect their double investment in human and financial capital.

Moreover, participation of employee shareholders in decision-making weakens managers' control bodies and, in particular, the financial market (Gordon \& Pound, 1990). In this regard, employee ownership can be used by the management team as an anti-takeover strategy (Gamble, 2000; Gharbi, 2006).

Overall, the debate on the effects of employees-shareholders ownership on financial performance in the context of corporate governance is subject to controversy. It would be interesting to consider the consequences of the representation of employees-shareholders in the supervisory bodies of French companies after the introduction of the 2006 Act.

In the absence of a consensus on the theoretical and empirical effects of a governance by employee shareholders on financial performance, it seems legitimate to ask the following question: What are the consequences of the participation of employee shareholders in corporate governance on financial performance?

Our study aims at contributing to a better understanding of the employee ownership-performance relationship under corporate governance in a French context.

\section{METHODOLOGY}

To investigate the consequences of the representation of employees-shareholders in supervisory bodies, we examine a sample of listed firms before and after the entry into force of these legal provisions.

Firms are issued from the SBF 250 between 2003 and 2012. Therefore, our sample panel totaled 1080 observations (108 firms x 10 years).

To this end, we opted for an approach based on panel data estimation. This bi-dimensional technique allows appreciating, simultaneously, data's dynamic behaviour and their possible heterogeneity. This is not the case with time series or cross-sectioned data.

It also takes into account the influence of unobservable characteristics of data when they remain stable over time (Sevestre, 2002).

Data were collected from several sources. Those relating to the characteristics of employee-shareholders and directors representing employee-shareholders are taken from the annual reports of companies filed to the AMF (authority of financial market).

The data on financial performance and those related to control variables were collected primarily through referenced documents and databases (Diane Thomson One Banker).

\section{Operationalization of Variables}

Independent Variables: Employee Ownership Variables/Corporate Governance Variables

The first variable is binary. It corresponds to the presence (coded 1) or absence (coded 0) of employee ownership (variable PO) (D’Arcimoles \& Trébucq 2003; Hollandts et al., 2008; Poulain Rhem, 2006; Trébucq, 2002). 
The second variable is continuous and corresponds to employee ownership rate measured by the percentage of capital held by employees (variable RO) (D’Arcimoles \& Trébucq 2003; Gamble, 2000; Hollandts et al., 2008; Trébucq, 2002).

To determine the effects of the legal requirements for the representation of employees-shareholders, we retain a variable expressing the presence or absence of an employees-shareholders ownership rate of $3 \%$ or more (TAS variable (1.0)).

Directors representing employee-shareholders, elected by shareholders-employees, represent an additional employee director, because of their membership to a labour union (unioniste) (Hollandts et al., 2011). It is thus necessary to make the difference between employees directors, directors representing employee-shareholders, and employee-shareholders directors (directors coming from an association or a member of employee-shareholding (FCPE of employee-shareholders).

Presence of directors holding shares in the company promotes aligning their interests with those of external shareholders (Jensen \& Warner, 1988). To effectively controlling managers, directors would work in their own interests identified with that of other shareholders.

Agency theory emphasizes the importance of stock ownership by members of the board in the effectiveness of control (Hillman \& Dalziel, 2003).

Thus, financial involvement of directors and their personal assets exposure to business risk induce them to effectively monitor management (Kosnik, 1990; Jensen \& Warner, 1988, Shleifer \& Vishny, 1986; Walsh \& Seward, 1990).

In this context, a first measure of the effectiveness of control undertaken by representatives of employeeshareholders in the board of directors can be envisaged through two variables:

Variable 1: Directors issued from an association of employee shareholders or a member of employeeshareholding (FCPE).

Variable 2: Unionists or elected directors.

However, if we consider the analysis of Hollandts et al. (2011), for the same level of financial capital investment, efficiency of directors representing employee shareholders within control bodies depends on their human capital endowment. "Indeed, the importance of human capital, its specificity to the company and its low rotation on the labour market (Blair et al., 2000) play a role in the effectiveness of control by employee-shareholders directors."

According to theory, younger workers are better endowed with human capital (Degeorge et al., 2004). Regarding degree of specificity to the company, economists often retain, as a measure, employee's seniority within the company.

Given these observations, we retain seniority for directors representing employee shareholders in their company and their age as two variables.

On the other hand, the literature emphasizes the importance of seniority for directors (Hollandts et al., 2011). Seniority promotes greater organizational commitment (Buchanan, 1974) of directors, a shared understanding of the rules of the group (Alderfer, 1986) and a higher resistance to pressure from external shareholders (Kosnik, 1990).

However, some authors oppose such an analysis, considering seniority of the directors as a factor facilitating management rooting (Hermalin \& Weisbach, 1988). 
The role and capacity to influence directors representing employee-shareholders are also related to the proportion of capital held by employees. "Power of employee-shareholders is measured by the ability to influence decisions of the board (...) Their motivation to effectively control managers is an increasing function of firm-specific investment in both human capital and equities" Desbrières (2002, p. 264).

The importance of the share capital held by employees (often measured by the percentage of employee ownership) relates to the company's capital structure. Presence of an external shareholder holding a blocking minority (33\% of capital according to d'Arcimole \& Trébucq, 2003; Desbrières, 2002; Trébucq, 2002; Hollandts et al., 2008) has no influence on the role that employee shareholders may have in the company.

Summary of independent variables:

- $\quad$ Presence of employee ownership plans (variable PEO)

- $\quad$ Presence of directors representing employee shareholders (variable PDO)

- $\quad$ Number of directors representing employee shareholders (variable NDO)

- $\quad$ Presence of unioniste (or elected) directors representing employee shareholders (variable PUD)

- $\quad$ Number of unioniste (or elected) directors representing employee shareholders (variable NUD)

- $\quad$ Presence of directors member of FCPE representing employee shareholders (variable PDFC)

- $\quad$ Number of directors member of FCPE representing employee shareholders (variable NDFC)

- $\quad$ Directors seniority within the company (variable SDC)

- $\quad$ Seniority in the position of directors (variable SDD)

- $\quad$ Age of employee-shareholders directors (variable AD)

- $\quad$ Employee ownership rate (RO)

- $\quad$ Presence or absence of an employee-shareholders ownership rate of 3\% or more (TAS)

The Dependent Variables: Financial Performance

Empirical studies examining financial performance generally rely on from the accounting and/or market measures.

- $\quad$ ROA (Return on Asset) is economic profitability which measures in percentage the ratio between net income and net assets mobilized in the activity (McGuire et al., 1963).

- $\quad$ PBR (Price to book ratio): measures stock market performance (D’Arcimoles \& Trébucq; Hollandts et al., 2008; Hollandts et al., 2011).

\section{The Control Variables}

Our study includes five control variables to improve the external validity of the results (Thiétardt, 1999). Size was operationalized as the turnover and workforce logarithm. Company performance should be evaluated in relation to the performance of the business sector. The inclusion of this variable is made according to the nomenclature of Euronext.

We segmented firms into two main business sectors:

S0: $\quad$ service + trade sector

S1: industry sector

We retain a variable measuring the presence/absence of an external shareholder holding a blocking minority (33\% of capital according to d'Arcimoles \& Trébucq, 2003; Desbrières, 2002; Hollandts et al., 2008; Trébucq, 2002).

To measure the relationship intensity between employee ownership and financial performance, the dimension 'time' represented by the duration of the presence of employee ownership seems essential (D 'Arcimoles \& Trébucq, 2003; Hollandts et al., 2008; Klein \& Hall, 1988). 
Summary of control variables:

- $\quad$ Annual Turnover (AT)

- $\quad$ Employees (E)

- $\quad$ Sector of activities (S)

- $\quad$ The presence/absence of external majority shareholder (variable EMS)

- $\quad$ Duration of employee ownership (DES)

\section{ANALYSIS AND DISCUSSION OF RESULTS}

To determine the nature of the effect of employee ownership on financial corporate performance, we established a linear model as independent variables and company performance.

Table 1: Regressions Results

\begin{tabular}{|c|c|c|c|c|c|c|}
\hline \multirow[b]{2}{*}{ Variables } & \multicolumn{3}{|c|}{ PBR } & \multicolumn{3}{|c|}{ ROA } \\
\hline & Value Estimated & Error Type & $\operatorname{Pr}>|t|$ & $\begin{array}{c}\text { Value } \\
\text { Estimated }\end{array}$ & Error Type & $\operatorname{Pr}>|t|$ \\
\hline PEO & -9.9120 & 0.5109 & $0.0456 * *$ & -4.0951 & 8.0912 & $0.0021 * * *$ \\
\hline NDO & -0.0076 & 5.6310 & $0.0473 * *$ & 1.9042 & 2.9053 & 1.5400 \\
\hline PDO & -0.0453 & 0.6434 & $0.0010 * * *$ & -0.4319 & 1.9812 & $0.0015 * *$ \\
\hline PUD & -0.0012 & 0.8754 & $0.0025 * * *$ & -3.0473 & 3.1934 & $0.0919 *$ \\
\hline NUD & -2.8709 & 0.8704 & 1.9410 & -2.9521 & 3.0098 & 2.6080 \\
\hline PDFC & -0.1101 & 0.0104 & $0.08410 *$ & -0.1501 & 3.0010 & $0.0400 * *$ \\
\hline NDFC & -5.0011 & 0.5101 & $0.0140 * *$ & -6.1115 & 5.0310 & $0.0327 * *$ \\
\hline TAS & -1.1030 & 2.0181 & $0.0151 * *$ & -2.1060 & 1.1161 & $0.0305 * *$ \\
\hline RO & 0.3421 & 3.0065 & 0.1200 & -1.0956 & 4.3109 & 0.9421 \\
\hline DES & 1.0531 & 0.9812 & 1.0965 & -2.0928 & 1.9041 & 0.1931 \\
\hline SDC & -3.7631 & 1.7510 & 2.2876 & -8.0071 & 1.0712 & $0.0564 *$ \\
\hline SDD & -1.1111 & 3.0530 & 5.6901 & -3.0411 & 1.0241 & 0.0612* \\
\hline $\mathrm{AD}$ & 5.0071 & 2.5981 & 4.0419 & 6.9975 & 5.8310 & 0.0942* \\
\hline EMS & 4.3018 & 1.0841 & 2.9821 & 6.1096 & 8.8412 & 0.4309 \\
\hline AT & -7.0057 & 1.0417 & 0.8518 & -1.2985 & 9.5410 & 0.8210 \\
\hline $\mathrm{E}$ & -8.7319 & 4.0082 & 1.0081 & -10095 & 5.9712 & 0.8862 \\
\hline S0 & -5.9710 & 2.0189 & 1.0951 & -6.9060 & 1.9961 & 0.4308 \\
\hline S1 & -7.0061 & 0.0002 & 0.9590 & 5.0971 & 5.0123 & 0.8120 \\
\hline
\end{tabular}

Significance levels: $1 \%, 5 \%, 10 \%$

Table 1 above shows that there is a significant negative relationship between presence of employee stock ownership plans and financial performance of the studied companies (the correlation coefficients between the variable PEO and two models of performance (ROA and PBR) are negative: -9.9120 and -4.0951).

The analysis of corporate governance variables shows that there are five significant relationships between financial performance variables and variables representing participation of employee shareholders in corporate governance.

On the one hand, there is a first negative correlation between presence of employee-shareholders directors issued of an association or a member of employee shareholding (FCPE) (variable PDFC) and their number (variable NDFC) and the two performance models (PBR and ROA). On the other hand, directors coming from a trade union or elected by employees negatively affect stock market performance (PBR) and economic profitability (ROA) with coefficients in the range of -0.0012 and -3.0473 . Therefore, our results indicate that participation of employee shareholders in corporate governance is negative.

Bad performances of firms, which favoured representation of employee shareholders in the control bodies (board of directors or board of trsutees), could be explained by managerial rooting practices. This is confirmed by the negative relationship between employees-shareholders ownership rate of 3\% or more (TAS variable) and two financial performance indicators. This result can be explained by the fact that administrators representing employee- 
shareholders are not sufficiently independent because of their membership in associations of employeesshareholders financed largely by the management team. This will favour accordingly entrenchment and weaken the disciplinary function of corporate governance.

The literature emphasizes that employee ownership and board representation offer an additional opportunity for rooting managers (Gordon \& Pound, 1990; Pugh Jahera \& Oswald, 1999). In general, managers often accused of influencing appointment of directors to establish their dominance over the board try to encourage the presence of loyal directors and to remove directors who might challenge them.

Human capital endowment measured by directors' age and seniority within the company as well as within the board negatively relates to performance indicators. This result is consistent with the findings of some authors who considered directors' seniority as a factor facilitating management rooting (Hermalin \& Weisbach, 1988). These results confirm the use of employee ownership by managers for purposes of rooting, which can be detrimental to value creation.

The presence of employee shareholders in the control bodies assumes reinforcement of leadership decisions and strengthening of their power in the company (Gharbi, 2006). In this regard, employee ownership is considered as a managerial entrenchment lever (Desbrières, 1997, 2002, Gamble, 2000; Gharbi, 2006) that consequently reduces value creation.

Ownership plans allow managers to defend themselves against possible takeovers and, therefore, to extend the life of the company and to consolidate their power by taking advantage of the voting rights of employee shareholders. The weight of employee shareholders, in terms of voting rights, therefore reduces greatly the likelihood of a takeover (Beatty, 1995; Chaplinsky \& Niehaus, 1994).

Empirically, several studies confirm the hypothesis that participation of employee shareholders in corporate governance promotes managerial entrenchment.

Gamble (2000) emphasizes that employees are not sufficiently independent of managers and that they dispose of implicit contracts based on tacit cooperation between both parties. This bilateral rooting (Faley et al., 2006) causes a decrease in the intensity of the control on executives exercised by the directors representing employee shareholders in return for guarantees mainly of employment and wages (Gharbi \& Lepers, 2008).

Rauh (2004) shows that the clear and immediate goal for establishing employee ownership is to erect barriers to hostile takeovers and, therefore, better protect managers from risks of layoff and replacement. Pugh, Jahera, and Oswald (1999) note that ESOPs increase managers' authority in the firm, if they are considered "friends." The new shareholders are seen in this case, as allies to managers.

Moreover, Chang (1990) states that in the presence of defensive ESOPs, shareholders believe that the voting rights attached to shares are controlled by executives who, pursuing a strategy of rooting, look for escaping market discipline for better corporate control.

Representation of employee shareholders in the control bodies has an effect on managers' behaviour. The latter, using the voting rights attached to shares held by employees, can strengthen their position in the company and consolidate their influence.

They can give more willingly to waste policies that could lead to a significant reduction in financial performance (Trébucq, 2002).

\section{CONCLUSION}

The study of employees-shareholders ownership in the context of corporate governance confirms the managerial entrenchment hypothesis when employees-shareholders are represented in decision-making. This empirical evidence simply reinforces the idea of a potential alliance between administrators representing employeesshareholders and managers at the expense of shareholders' value creation. 
Representation of employee shareholders leads to a reduction in control efficiency because of the hierarchical dependence of the directors representing employee shareholders (Gharbi \& Lepers, 2008; Hollandts et al., 2011). These can have a negative impact on business objectives by fostering managers' opportunistic behaviour.

The hypothesis of a coalition between employee shareholders and the manager seems to be confirmed by several empirical studies. The presence of employee shareholders in the control bodies involves the reinforcement of managers' decisions and the strengthening of their power in the company (Gharbi, 2006).

In this sense, employee ownership is considered as a managerial entrenchment lever (Desbrières, 1997, 2002; Gamble, 2000; Gharbi, 2006) that consequently reduces value creation.

This representation became mandatory since the entry into force of the 30 December 2006 Law, providing executives an additional opportunity to strengthen their position within the company and allow them to engage in all rooting practices without external control.

Indeed, as suggested by several authors like Hollandts et al. (2011), presence of administrators representing employees-shareholders in this kind of companies belonging to associations of employees-shareholders largely funded by the company's management board calls into question their independence.

The effects of such a law can affect the very development of employees-shareholders ownership as recalled by Hollandts et al. (2011). Indeed, the board of directors or supervisory board can prevent the representation of employees-shareholders minimizing employees-shareholders ownership plans so that they do not reach the threshold of $3 \%$ of capital that makes their representation mandatory.

Overall, theory-wise our study suggests that the representation of employees-shareholders in supervisory bodies enhances managerial entrenchment. This finding reinforces the literature insisting that employeesshareholders ownership is a practice and a tool for managerial opportunism (Desbrières 2002; Gharbi 2006; Hollandts et al., 2008 Hollandts \& Guedri, 2008; Trébucq, 2002).

Management-wise, we believe that the 30 December 2006 law reinforcing the representation of employeesshareholders in corporate governance in which they hold at least $3 \%$ of the capital favours entrenchment insofar as the latter are supported by inside managers (Hollandts et al., 2008) position.

However, to limit excesses of this reform, it might be provisioned a battery of measures aimed at reducing the influence of managers on administrators representing employees-shareholders. Independence of the latter will depend, of course, on their membership to associations that are previously funded by managers.

\section{AUTHOR INFORMATION}

Tarek Ben Noamene, Assistant Professor, Department of Management, University of Law, Economics, and Management of Jendouba, Avenue de l'UMA 8189 Jendouba, Tunisia. E-mail: tarek.noa@ gmail.com

\section{REFERENCES}

1. Alderfer, C. (1986). The invisible director on corporate boards. Harvard Business Review, 64(6), 38-50.

2. Autenne, A. (2005). Analyse économique du droit de l'actionnariat salarié. Bruxelles: Bruylant Bibliothèque de la Faculté de Droit de l'Université Catholique de Louvain.

3. Beatty, A. (1995). The cash flow and informational effects of employee stock ownership plans. Journal of financial Economics, 38, 211-240.

4. Blair, M., Kruse, D., \& Blasi, J. (2000). Employee ownership: An unstable form or a stabilizing force. In M. M. Blair \& T. Kochan (eds), The new relationship: Human capital in the American corporation. Washington D.C.: Brookings lnstitution Press.

5. Buchanan, B. (1974). Building organizational commitment: The socialization of managers in work organizations. Administrative Science Quarterly, 19, 533-546. 
6. Cable, J., \& Fitzroy, F. (1980). Productive efficiency, incentives and employee participation: Some preliminary results for West Germany. Kyklos, 33(1), 100-121.

7. Chang, S., \& Mayers, D. (1992). Managerial vote ownership and shareholder wealth. Journal of Financial Economics, 32, 103-131.

8. Chang, S. (1990). Employee stock ownership and shareholder wealth: An empirical investigation. Financial Management, 19(1), 48-58.

9. Chaplinsky, S., \& Niehaus, G. (1994). The role of ESOPs in takeover contests. Journal of Finance, 49(4), 1451-1470.

10. Charreaux, G. (1997a). Vers une théorie du gouvernement des enterprises. In Le Gouvernement des Entreprises, Charreaux G. (ed.), coll. Recherche en Gestion, Économica, 421-469.

11. Charreaux, G. (1997b). Mode de contrôle des dirigeants et performance des firmes. In Le Gouvernement des Entreprises, Charreaux G. (ed.), coll. Recherche en Gestion, Économica, 17-54.

12. Charreaux, G. (1997c). Conseil d'administration et pouvoir dans l'entreprise. In Le Gouvernement des Entreprises, Charreaux G. (ed.), coll. Recherche en Gestion, Économica, 141-164.

13. Charreaux, G. (1999). La théorie positive de l'agence: lectures et relectures. In Des nouvelles théories pour gérer l'entreprise au XXIe siècle, Koenig G. (coord.), Économica.

14. Conte, M., Blasi, J., Kruse, D., \& Jampani, R. (1996). Financial returns of public ESOP companies: Investors effects vs. manager effect. Financial Analyst Journal, 52, 50-60.

15. D'Arcimoles CH-H et Trébucq S. (2003). Une approche du rôle de l'actionnariat salarié dans la performance et le risque des entreprises françaises. Revue de Gestion des Ressources Humaines, 48, 2-15.

16. Degeorqe F., Jenter D., Moel A., \& Tufano P. (2004). Selling company shares to reluctant employees: France telecom's experience. Journal of Financial Economics, 71(1), 169-202.

17. Desbrières, P. (2002). Les actionnaires salaries. Revue Française de Gestion, 28(141), 255-281.

18. Desbrières, P. (1997). Le rôle de l'actionnariat des salariés non-dirigeants dans le système de gouvernement de l'entreprise. C. G. (Éd) Recherche en Gestion.

19. Dhillon S., \& Ramirez G. (1994). Employee stock ownership and corporate control: An empirical study. Journal of Banking \& Finance, 18(1), 9-25.

20. Fama, E., \& Jensen, M. (1983). Separation of ownership and control. Journal of Law and Economics, 26, 301-326.

21. Fama, E. (1980). Agency problems and the theory of the firm. Journal of Political Economy, 88, 50-62.

22. Gamble, J. (2000). Management commitment to innovation and ESOP stock concentration. Journal of Business Venturing, 15, 433-447.

23. Gharbi, H. (2006). Actionnariat salarié et enracinement des dirigeants. Thèse de Doctorat en Sciences de Gestion, Université Paris Dauphine.

24. Gharbi, H., \& Lepers, X. (2008). Actionnariat salarié et enracinement des dirigeants: un essai de compréhension. Revue Innovation, 1(27).

25. Gordon, L., \& Pound, J. (1990). ESOPs and corporate control. Journal of Financial Economics, 27, 525555.

26. Hermalin, B., \& Weisbach, M. (1988). The determinants of board composition. The Rand Journal of Economics, 19, 589-606.

27. Hillman, A., \& Dalziel, T. (2003). Board of directors and firm performance: Integrating agency and resource dependent perspectives. Academy of Management Review, 8(23), 383-396.

28. Hollandts, X., \& Guedri, Z. (2008). Effet modérateur de la présence d'administrateurs salariés sur la relation actionnariat salarié-performance: une analyse empirique. XVIe Conférence Internationale de Management Stratégique. Montréal.

29. Hollandts, X., \& Aubert, N. (2011). La représentation obligatoire des actionnaires salariés au conseil d'administration: un état des lieux. Gestion 2000, 28(6), 15-26.

30. Hollandts, X., Aubert, N., \& Eminet, A. (2008). La représentation obligatoire des actionnaires salariés au conseil d'administration: enjeux et conditions d'efficacité. Université Montesquieu Bordeaux-IV. Bordeaux: 7e Congrès International de Gouvernance.

31. Hollandts, X., Guedri, Z., \& Aubert, N. (2011). Les déterminants de la représentation des actionnaires salariés au Conseil d'administration ou de surveillance. Management International, 15(4), 69-83.

32. Jensen, M. C., \& Meckling, W. H. (1976). Theory of the firm: Managerial behavior, agency costs and ownership structure. Journal of Financial Economics, 3(October), 305-360. 
33. Jensen M. C., \& Warner J. B. (1988). The distribution of power among corporate managers, shareholders and directors. Journal of Financial Economics, 20(3), 24.

34. Klein K., \& Hall R. (1988), Correlates of employee satisfaction with stock ownership: Who likes an ESOP Most. Journal of Applied Psychology, 73(4), 630-638.

35. Kosnik, R. (1987). Greenmail: A study of board performance in corporate governance. Administrative Science Quarterly, 32, 163-185.

36. McGuire, J. W. (1963). Business and society. New York: MacGraw-Hill.

37. Park, S., \& Song, M. (1995). Employee Stock ownership plans, firm performance, and monitoring by outside block holders. Financial Management, 24(4), 52-65.

38. Parrat, F. (1999). Le gouvernement d'entreprise: ce qui a déjà changé, ce qui va encore évoluer. Maxima/Laurent du Mesnil Editeur.

39. Pendleton, A. (2001). Employee ownership, participation and governance. A study of ESOPs in the UK, London and New York, Rutledge.

40. Pendleton, A., Wilson, N., \& Wright, M. (1998), The perception and effects of share ownership: Empirical evidence from employee buy-outs. British Journal of Industrial Relations, 36(1), 99-123.

41. Poulain-Rehm, T. (2006). L'actionnariat des salariés en France, un facteur de création de valeur? AFFI, Poitiers, 26-27 juin.

42. Pugh, W., Jahera, Jr., \& Oswald, L. (1999). ESOPs, takeover protection, and corporate decision-making. Journal of Economics and Finance, 23(2), 170-185.

43. Pugh, W., Oswald, L., \& Jahera, Jr. (2000). The effect of ESOP adoptions on corporate performance: Are there really performance changes? Managerial and Decision Economic, 21, 17-180.

44. Rauh, J. (2004). Own company stock in defined contribution pension plans: A takeover defense. (Working paper).

45. Sevestre, P. (2002). Économétrie des données de panel. Paris: Dunod.

46. Shleifer, A., \& Vishny, R. W. (1986). Large shareholders and corporate control. Journal of Political Economy, 95, 461-488.

47. Shleifer, A., \& Vishny, R. (1997). A survey of corporate governance. Journal of Finance, 52, $737-783$.

48. Thiétardt, R. A et Coll. (1999). Méthodes de recherche en management. Paris: Dunod.

49. Trébucq, S. (2002). L'actionnariat salarié dans les entreprises familiales du SBF250: un outil de création de valeur?. Finance Contrôle Stratégie, 5(4), 107-135.

50. Vaughan-Whitehead D. (1992). Intéressement, participation, actionnariat: Impacts économiques dans l'entreprise. Économica, Paris.

51. Walsh, J. P., \& Seward, J. K. (1990). On the efficiency of internal and external control mechanisms. Academy of Management Review, 15, 421-458.

52. Wirtz, P. (2000). Mental patterns, corporate finance and institutional evolution: The case of the French corporate governance system. (U. d. Dijon, Éd.) Working paper $n^{\circ} 1000101$ LEG-FARGO.

53. Zolezzi, G. (2004). L'actionnariat salarié influent face aux théories des droits de propriété et de la gouvernance partenariale. Métamorphoses des Organisations, GREFIGE, 21 et 22 Octobre 2004, Nancy. 


\section{$\underline{\text { NOTES }}$}

